\title{
Agronomic Techniques and Planting Systems Moderate Terminal Temperature Stress in Wheat
}

\author{
J.S. Kang, Harmeet Singh*, Maninder Kaur and Harrajdeep Kaur \\ Department of Agronomy, Punjab Agricultural University, Ludhiana-141004, India \\ *Corresponding author
}

\section{A B S T R A C T}

Keywords

Zero tillage,

Conventional

tillage,

Foliar application,

Crop Residue and

Temperature stress.

Article Info

Accepted:

17 May 2017

Available Online:

10 June 2017
Field studies were conducted on wheat at the PAU, Ludhiana during 200708 to 2009-10. The results revealed that wheat sown with zero tillage and conventional tillage gave the equivalent yield but conventional tillage with crop residue gave the considerably higher yield as compared to the former methods of planting. The foliar application of $\mathrm{KNO}_{3}(1 \%)$, with extra light irrigation (flooding) and sprinkling of irrigation water during post anthesis stage also gave the considerably more grain yield as compared to the recommended practices and green manuring (1:6) during 2007-08, 2008-09 and 2009-10. The magnitude of temperature changes the maturation of the crop resulting in small, wrinkled and shrunken grains during 2007-08 and 2009-10. The crop took 129, 154 and 145 days to maturity during 2007-08, 2008-09 and 2009-10, respectively.

\section{Introduction}

Wheat is a major cereal crop of Punjab. Wheat being the temperate crop, it does not tolerate a lengthened exposure to high temperatures crossing $350 \mathrm{C}$ and in many parts of the world, it experience high temperature during the grain fill period (Gusta and Chen, 1987). It has been observed the heat stress is one of the constraints to increase the productivity of wheat in the last few years in Punjab and with the high temperature during the post anthesis and grain-fill period, wheat yield is decreased by 2- $4 \mathrm{q} / \mathrm{ha}$. This much increase is possible with the judicious use of inputs and proper management in case of wheat. High temperature exposure of wheat may be the reason for drastic yield reduction as the most important phenological stage during grain filling is adversely affected and may cause shriveled and smaller grains. Rate and continuance of dry matter build - up is largely determined by temperature and final kernel weight is expected in this duration. Lesser the duration of filling, lower is the kernel weight. It has been proved by many worker that heat rise will mature the crop quickly resulting in shrunken and small grains (Sofield et al., 1977) Final kernel weight is determined by rate and duration of grain dry matter accumulation. Generally, lower kernel weight of heat stressed wheat is due to a reduced duration rather than a reduced rate of grain growth (Sofield et al., 1977, Warrington 
et al., 1977, Wiegand and Cuellar, 1981). Heat stress during grain fill hastens maturation of the crop resulting in small, shrunken grains (Sofield et al., 1977). The sensitivity of wheat crop's yield to high temperature, as ascertained by many workers is associated with quick augmentation, cut down in photosynthesis activity and a direct stroke on reproductive processes.

Relationship of impact of high temperature during flowering and lesser grain counts with a seriously antagonistic effect on grain yield has been proven experimentally and evidence are list (Barnabas et al., 2008). According to Porter and Gawith (1999), it is accepted that threshold temperature is $31^{\circ} \mathrm{C}$ for this crop at near flowering without making any serious impact on number of grains.

In a number of studies, it has been concluded that duration of 20 days before and 10 days after anthesis is the sensitive period for temperature stress and 5 days before and 2 days after anthesis being most sensitive Calderini et al., (1999), Wang et al., (2011), and Dias et al., (2011). Potential activity of assimilate production by photosynthesis in leaves and stems directs and execute grain filling stage, not only this but also nitrogen and carbohydrates are impelled and motivated (Plaut et al., 2004) for transference to sink (ear and grain). On the other hand photosynthesis is potentially incapacitated due to high temperature at this critical stage and affects grain weight of wheat very seriously.

In an experiment, at grain filling stage, seventy five wheat cultivars were exposed to short interlude of temperature above $35^{\circ} \mathrm{C}$ in Australia and it severely affected individual grain in the range of $23 \%$ to $37 \%$ in reducing their weight (Stone and Nicolas, 1994). It may have also affected and prevented starch biosynthesis in the endosperm cells as the temperature goes above $34^{\circ} \mathrm{C}$ (Dias and
Lidon, 2009). Some workers have also strongly associated senescence with grain filling (Barnabas, et al., 2008) in wheat because senescence is triggered by temperature above $35^{\circ} \mathrm{C}$ and further leaf senescence is still higher with more temperature. In Texas, USA, results revealed that during post heading stage, the number of quickly aged leaves (senescence) per individual tiller rose to ten from two when temperature was raised from $21^{\circ} \mathrm{C}$ to $28^{\circ} \mathrm{C}$ (Tewolde et al., 2006).

Wider daily fluctuation in temperature can trigger senescence of flag leaves in wheat under heat stress as compared to adjourned senescence under favorable temperature range of $26^{\circ} \mathrm{C} / 14^{\circ} \mathrm{C}$ (Zhao et al., 2007). The objective of this study was to moderate the high temperature effects on productivity of wheat in Punjab.

\section{Materials and Methods}

Field studies were carried out to mitigate the ill effect of high temperature on the productivity of wheat at Punjab Agricultural University, Ludhiana for three consecutive years from 2007-08 to 2009-10. The treatments consist of three methods of crop establishment in main plots such as Zero tillage, Conventional tillage and Conventional tillage with mulching at $2 \mathrm{t} / \mathrm{ha}$ of paddy straw and five treatments as foliar spray of Potassium nitrate $(1 \%)$ during anthesis stage, one extra light irrigation, sprinkling irrigation water during post anthesis, sowing of dhiancha in 1:6 ratio and recommended practices.

The experimental soil was sandy loam having $\mathrm{pH} 8.0$, organic carbon $0.26 \%$, available phosphorus $14.7 \mathrm{~kg} / \mathrm{ha}$ and available potassium $298 \mathrm{~kg} / \mathrm{ha}$, therefore, the fertility status was low. The experiments were laid out in strip plot design and treatments were replicated three times in gross plot size of 10 
$\mathrm{m} \times 2.10 \mathrm{~m}$. The variety PBW 343 of wheat was sown on 30-11-2008 and 01-12-2009 during 2008-09 and 2009-10, respectively but in 2007-08, it was sown on 16-12-2007.

Under the zero tillage treatment, the crop was sown with zero till drill, in the conventional tillage seed bed was prepared by giving two time discing and two time cultivators and one time planking and crop was sown with the traditional drill. In the mulching treatments, after sowing the crop immediately apply the mulching. All the other practices followed recommended to raise the crop. The crop was harvested on 24-04-2008, 03-05-2009 and 2504-2010.

\section{Results and Discussion}

\section{Plant height (cm)}

Plant height did not varied non-significantly (Table 1) with different crop establishment methods during all the years of study, although highest height was recorded from crop raised in conventional tillage with crop in second year only.

Foliar spray of Potassium nitrate (1\%) during anthesis stage, one extra light irrigation, sprinkling irrigation water during post anthesis, sowing of dhiancha in 1:6 ratio and recommended practices also could not affect the gain in height of plant and were statistically at par.

\section{Ear length (cm)}

Ear length of the plant had not responded to different treatments of planting (Table 1) and non-significantly results were observed with different crop establishment methods during all the years. Even different manipulation like Foliar spray of Potassium nitrate (1\%) during anthesis stage, one extra light irrigation, sprinkling irrigation water during post anthesis, sowing of dhiancha in 1:6 ratio and recommended practices could not affect the ear length in three year of study.

\section{Effective tillers and 1000 grain weight}

1000 grain weight and effective tillers of wheat was not influenced by different crop establishment methods (Table 1) during three years of study. A slight increase in 1000 grain weight and effective tillers during second year was observed but results were non-significant.

Different agronomic manipulations also did not influence the 1000 grain weight and effective tillers although increasing trend in second year was seen from other years. Grain test weight varied non-significantly with different crop establishment methods during all the years of study but numerically higher under conventional tillage with crop residue as compared to zero tillage and conventional tillage. Mulching creates the favorable conditions like increase the availability of moisture for longer period and keep the low soil temperature in the post anthesis and grain-fill period.

The grain test weight values were higher under the potassium nitrate, one extra irrigation and sprinkling of water during post anthesis stage than the recommended practices and green manuring treatments in all the years of study. Variation in grain test weight between the three years indicates high temperature stress during the grain fill period of wheat crop. Obviously grain test weight is ultimately affected due stress of high temperature as the efficiency of utilizing assimilates is directly reduced as discussed by Sofield et al., 1977 and Wlegand and Ceullar, 1981. Potential activity of assimilate production by photosynthesis in leaves and stem is directs and execute grain filling stage, not only this but also nitrogen and carbohydrates are impelled \& motivate (Plaut et al., 2004) for progressive transference to sink (ear and grain). 
Table.1 Influence of crop establishment methods and different manipulations on growth and Yield attributes of wheat sown under late conditions

\begin{tabular}{|c|c|c|c|c|c|c|c|c|c|c|c|c|}
\hline Treatment & \multicolumn{3}{|c|}{ Plant height $(\mathrm{cm})$} & \multicolumn{3}{|c|}{ Ear length $(\mathrm{cm})$} & \multicolumn{3}{|c|}{1000 grain weight } & \multicolumn{3}{|c|}{ Effective tillers } \\
\hline $\begin{array}{l}\text { Crop } \\
\text { establishment }\end{array}$ & $\begin{array}{l}1^{\text {st }} \\
\text { Year }\end{array}$ & $\begin{array}{l}2^{\text {nd }} \\
\text { Year }\end{array}$ & $\begin{array}{l}3^{\text {rd }} \\
\text { Yeal }\end{array}$ & $\begin{array}{l}1^{\text {st }} \\
\text { Year }\end{array}$ & $\begin{array}{l}2^{\text {nd }} \\
\text { Year }\end{array}$ & $\begin{array}{l}3^{\text {rd }} \\
\text { Year }\end{array}$ & $\begin{array}{l}1^{\text {st }} \\
\text { Year }\end{array}$ & $\begin{array}{l}2^{\text {nd }} \\
\text { Year }\end{array}$ & $\begin{array}{l}3^{\text {rd }} \\
\text { Year }\end{array}$ & $\begin{array}{l}1^{\text {st }} \\
\text { Year }\end{array}$ & $\begin{array}{l}2^{\text {nd }} \\
\text { Year }\end{array}$ & $\begin{array}{l}3^{\text {rd }} \\
\text { Year }\end{array}$ \\
\hline ZT & 69.2 & 80.3 & 69.5 & 9.0 & 9.8 & 9.5 & 38.2 & 40.6 & 38.1 & 95.7 & 103.2 & 96.1 \\
\hline CT & 69.3 & 79.7 & 69.6 & 9.0 & 9.7 & 9.5 & 38.4 & 40.7 & 38.2 & 95.2 & 102.4 & 97.1 \\
\hline CTCR & 69.2 & 80.8 & 69.5 & 9.6 & 9.8 & 9.7 & 38.6 & 41.7 & 38.5 & 97.3 & 102.4 & 99.3 \\
\hline $\mathrm{CD}(\mathrm{p}=0.05)$ & $\mathrm{NS}$ & $\mathrm{NS}$ & NS & NS & NS & $\mathrm{NS}$ & NS & NS & NS & $\mathrm{NS}$ & NS & NS \\
\hline \multicolumn{12}{|c|}{ Different manipulations } & \\
\hline $\mathrm{KNO}_{3}(1 \%)$ & 70.0 & 78.6 & 70.7 & 9.2 & 10.0 & 9.8 & 39.8 & 41.9 & 39.1 & 97.5 & 109.6 & 98.9 \\
\hline $\begin{array}{ll}\text { Extra } & \text { one } \\
\text { irrigation } & \end{array}$ & 69.8 & 80.0 & 69.9 & 9.3 & 10.0 & 9.7 & 39.6 & 41.4 & 39.0 & 97.1 & 103.4 & 98.5 \\
\hline $\begin{array}{l}\text { Recommended } \\
\text { practice }\end{array}$ & 68.4 & 79.6 & 68.2 & 9.5 & 9.6 & 9.3 & 36.8 & 40.9 & 36.0 & 95.0 & 96.8 & 96.4 \\
\hline Sprinkling water & 69.2 & 78.5 & 69.2 & 9.3 & 9.9 & 9.6 & 39.5 & 41.0 & 38.5 & 96.4 & 101.6 & 97.8 \\
\hline $\begin{array}{l}\text { Green manuring } \\
(1: 6)\end{array}$ & 68.5 & 79.9 & 69.5 & 9.3 & 9.6 & 9.2 & 36.9 & 40.8 & 35.1 & 95.6 & 101.9 & 96.0 \\
\hline $\mathrm{CD}(\mathrm{p}=0.05)$ & $\mathrm{NS}$ & NS & NS & NS & NS & $\mathrm{NS}$ & NS & NS & NS & $\mathrm{NS}$ & NS & NS \\
\hline
\end{tabular}

ZT-Zero tillage, CT- Conventional tillage, CTCR- Conventional tillage with crop residue

Table.2 Influence of crop establishment methods and different manipulations on grain Yield of wheat sown under late conditions

\begin{tabular}{|l|c|c|c|}
\hline \multirow{2}{*}{ Treatment } & \multicolumn{3}{|c|}{ Grain yield(q/ha) } \\
\cline { 2 - 4 } & $1^{\text {st }}$ Year & $2^{\text {nd }}$ Year & $3^{\text {rd }}$ Year \\
\hline Method of establishment & 34.6 & 54.7 & 42.1 \\
\hline Zero tillage & 33.3 & 55.5 & 42.4 \\
\hline Conventional tillage & 35.9 & 56.9 & 44.4 \\
\hline $\begin{array}{l}\text { Conventional tillage } \\
\text { with residue }\end{array}$ & NS & $\mathbf{0 . 8}$ & NS \\
\hline CD (p=0.05) & 36.4 & 58.9 & 43.8 \\
\hline Different manipulation & 35.5 & 57.8 & 43.3 \\
\hline KNO 3 (1\%) & 33.1 & 52.9 & 41.7 \\
\hline $\begin{array}{l}\text { Extra one irrigation } \\
\text { flooding) }\end{array}$ & 35.0 & 56.7 & 43.6 \\
\hline Recommended practice & 33.0 & 51.1 & 41.0 \\
\hline Sprinkling of water & $\mathbf{N S}$ & $\mathbf{3 . 3}$ & NS \\
\hline Green manuring (1:6) & \multicolumn{3}{|l|}{} \\
\hline CD(p=0.05) & \multicolumn{3}{|l|}{} \\
\hline
\end{tabular}


Table.3 Mean monthly temperature and rainfall monthly during the growing season

\begin{tabular}{|l|c|c|c|c|c|c|}
\hline \multirow{2}{*}{ Month } & \multicolumn{3}{|c|}{ Mean temperature $\left({ }^{0} \mathrm{C}\right)$} & \multicolumn{3}{c|}{ Rainfall $(\mathrm{mm})$} \\
\cline { 2 - 7 } & $2007-08$ & $2008-09$ & $2009-10$ & $2007-08$ & $2008-09$ & $2009-10$ \\
\hline October & 24.5 & 25.3 & 23.8 & - & $\mathbf{6 . 8}$ & - \\
\hline November & 18.6 & 19.6 & 19.4 & - & $\mathbf{1 4 . 0}$ & 1.3 \\
\hline December & 12.6 & 13.7 & 12.0 & - & $\mathbf{8 . 7}$ & 17.7 \\
\hline January & 12.5 & 11.8 & 10.7 & 16.8 & $\mathbf{1 0 . 0}$ & 16.3 \\
\hline February & $\mathbf{1 8 . 7}$ & $\mathbf{1 5 . 2}$ & 13.3 & 0.8 & $\mathbf{8 4 . 7}$ & 3.2 \\
\hline March & $\mathbf{2 0 . 0}$ & $\mathbf{1 9 . 3}$ & $\mathbf{2 2 . 2}$ & 32.5 & $\mathbf{4 1 . 3}$ & - \\
\hline April & 27.1 & 28.1 & 25.9 & 5.1 & $\mathbf{2 6 . 2}$ & 50.2 \\
\hline
\end{tabular}

Table.4 Influence of Crop establishment methods on infiltration rate $(\mathrm{cm})$ at Harvest during 2009-10

\begin{tabular}{|l|c|c|c|}
\hline Time (minutes) & Zero tillage & $\begin{array}{c}\text { Conventional } \\
\text { Tillage }\end{array}$ & $\begin{array}{c}\text { Conventional tillage } \\
\text { with crop residue }\end{array}$ \\
\hline 5 & 1.7 & 2.0 & 2.0 \\
\hline 10 & 3.4 & 2.9 & 3.3 \\
\hline 15 & 5.5 & 5.0 & 5.4 \\
\hline 30 & 8.6 & 7.4 & 7.4 \\
\hline 45 & 10.2 & 9.4 & 9.5 \\
\hline 60 & 13.4 & 11.4 & 12.8 \\
\hline 120 & 15.8 & 13.6 & 14.5 \\
\hline 80 & 18.6 & 16.2 & 16.8 \\
\hline
\end{tabular}

\section{Grain yield}

Grain yield of wheat was not influenced by different crop establishment methods during 2007-08 (first year) and 2009-10 (third year) but it was influenced in second year (2008-09) (Table 2). The crop sown with zero tillage and conventional tillage gave the similar grain yield but in 2008-09, grain yield was significantly higher under conventional tillage with crop residue. The increase in grain yield with the crop residue could be due to the higher growth and yield contributing attributes (Table 1). A significantly higher grain yield in 2008-09 could be due to the favorable mean monthly temperature (Table 3) and well distribution of rainfall during the growing season. Different agronomic manipulations did not influence the grain yield during 2007-08 and 2009-10 but had significant influence on grain yield during 2008-09. However, the foliar spray of potassium nitrate, application of one extra irrigation and sprinkling of water during post anthesis stage produced higher grain yield of wheat in all the years of study but these treatments produced the significantly more grain yield as compared to the recommended practices and green manuring treatments during 2008-09 because of well distribution of rainfall during the growing season and gradual increase in temperature in the grain filling stage as compared to the other years of study. The overall lower grain yield during 2007-08 was due to the high mean monthly temperature in the month of February and March, delayed sowing (16-12-2007) and in 2009-10 was due to abrupt increase in the temperature from 13.3 to 22.20C in the month of March means the high temperature during the grain fill period which ultimately cause the reduction in grain yield due to lower 1000 grain weight with the advancement in the maturity. Exposure of wheat crop to hot weather conditions at the important stage of grain filling would result in 
small \& shriveled grains. This may have been due to various reasons like severally affecting photosynthesis \& movements of assimilates to sink portion of the plant. Utilization of carbohydrates and nitrogen compound is also curtailed significantly (Bagga and Ramson, 1977; Choudhury and Wardlaw, 1978; Spertz, 1977; Evan et al., 1975 and Bhullar and Jerner 1985, 1986; Plaut et al., 2004 and Dias and Lidon, 2009).

\section{Infiltration rate}

The infiltration rate was higher in case of zero tillage and conventional tillage with crop residue at harvest than conventional tillage (Table 4). It could be the minimum disturbance of soil in case of zero tillage treatment means no breakage of water capillaries in the soil and in case of mulching treatment loosening of soil due to decomposition of mulching material.

\section{Mean monthly temperature}

Mean monthly temperature was increased 6.2, 3.4 and $2.60 \mathrm{C}$ in the month of February than January and 1.3, 4.1 and $8.90 \mathrm{C}$ in the month of March than February during 2007-08, 2008-09 and 2009-10, respectively (Table 3). It shows crop exposed to high temperature in the month of February and March during 2007-08 and 2009-10, respectively however, the temperature increased gradually in the month of February and March during 2008-09. In this year (200809), overall yield was quite high than the other years because of gradual increase in temperature in the grain-fill period and distribution of rainfall during the growing season. However, in 2009-10 and 2009-10 the temperature was high during the grain filling stage of the crop which is a main reason of low productivity of wheat.

\section{References}

Bagga, A.K. and Rawson, H.M. 1977. Contrasting response of morphologically similar wheat cultivars to temperatures appropriate to warm temperature climates with hot summers: A study in controlled environments. Aust. J. Plant Physiol., 4: 877-887.

Barnabás, B., Jäger, K. and Fehér, A. 2008. The effect of drought and heat stress on reproductive processes in cereals. Plant, Cell Environ., 31(1): 11-38.

Bhullar, S.S. and Jenner, C.F. 1985. Differential response to high temperature of starch and nitrogen accumulation in the grain of four cultivars of wheat. Aust. J. Plant Physiol., 12: 363-375.

Bhullar, S.S. and Jenner, C.F. 1986. Effects of temperature on conversion of sucrose to starch in the developing wheat endosperm. Aust. J. Plant Physiol., 13: 605-615.

Calderini, D., Abeledo, L., Savin, R. and Slafer, G.A. 1999. Effect of temperature and carpel size during pre-anthesis on potential grain weight in wheat. J. Agri. Sci., 132(04): 453-459.

Choudhury, S.I. and Wardlaw, I.F. 1978. The effect of temperature on kernel development in cereals. Aust. J. Agric. Res., 29: 205-223.

Dias, A. and Lidon, F. 2009. Evaluation of grain filling rate and duration in bread and durum wheat, under heat stress after anthesis. J Agron. Crop Sci., 195(2): 137147.

Dias, A., Semedo, J., Ramalho, J. and Lidon, F. 2011. Bread and durum wheat under heat stress: a comparative study on the photosynthetic performance. J. Agron. Crop Sci., 197(1): 50-56.

Evans, L.T., Wardlaw, I.F. and Fischer, R.A. 1975. Wheat. In L.T. Evans (Ed.) Crop physiology, Cambridge Univ. Press, London, pp. 101-149.

Farooq, M., Bramley, H., Palta, J.A. and Siddique, K.H. 2011. Heat stress in wheat during reproductive and grain-filling phases. Crit. Rev. Plant Sci., 30(6): 491507

Gusta, V., and Chen, H.H. The physiology of water and temperature stress. In E.G. Heyne (Ed.) Wheat and wheat 
improvement. 1987. $2^{\text {nd }}$ edn. Agron., 13: 115-150.

Hays, D.B., Do, J.H., Mason, R.E., Morgan, G. and Finlayson, S.A. 2007. Heat stress induced ethylene production in developing wheat grains induces kernel abortion and increased maturation in a susceptible cultivar. Plant Sci., 172(6): 1113-1123.

Luo, Q. 2011. Temperature thresholds and crop production: a review. Climatic Change, 109(3-4): 583-598.

Mitchell, R., Mitchell, V., Driscoll, S., Franklin, J. and Lawlor, D. 1993. Effects of increased $\mathrm{CO}_{2}$ concentration and temperature on growth and yield of winter wheat at two levels of nitrogen application. Plant, Cell Environ., 16(5): 521-529.

Plaut, Z., Butow, B., Blumenthal, C. and Wrigley, C., 2004. Transport of dry matter into developing wheat kernels and its contribution to grain yield under postanthesis water deficit and elevated temperature. Field Crops Res., 86(2): 185-198.

Porter, J.R. and Gawith, M. 1999. Temperatures and the growth and development of wheat: a review. Eur. J. Agron., 10(1): 23-36.

Semenov, M.A. 2009. Impacts of climate change on wheat in England and Wales. J. Royal Society Interface, 6(33): 343350.

Sofield, I., Evans, L.T., Cook, M.G. and Wardlaw, I.F. 1977. Factors influencing the rate and duration of grain filling in wheat. Aust. J. Plant Physiol., 4: 785-797.

Spiertz, J., et al. 2006. Heat stress in wheat (Triticum aestivum L.): Effects on grain growth and quality traits. Eur. J. Agron., 5(2): 89-95.

Spiertz, J.H.J. 1977. The influence of temperature and light intensity on grain growth in relation to carbohydrate and nitrogen economy of the wheat plant. Neth. J. Agric. Sci., 25: 182-197

Stone, P. and Nicolas, M. 1995. Effect of timing of heat stress during grain filling on two wheat varieties differing in heat tolerance. I. Grain growth. Funct. Plant Biol., 22(6): 927- 934.

Tewolde, H., Fernandez, C. and Erickson, C. 2006. Wheat Cultivars Adapted to Post- Heading High Temperature Stress. J. Agron. Crop Sci., 192(2): 111-120.

Wang, X. et al. 2011. Pre-anthesis hightemperature acclimation alleviates damage to the flag leaf caused by postanthesis heat stress in wheat. J. Plant Physiol., 168(6): 585-593.

Warrington, I.J., Dunstone, R.L. and Green, L.M. 1977. Temperature effects at three developmental stages on the yield of the wheat ear. Aust. J. Agric. Res., 28: 11-27.

Wiegand, C.L. and Cuellar, J.A. 1981. Duration of grain filling and kernel weight of wheat as affected by temperature. Crop Sci., 21: 95-101.

Yin, X., Guo, W. and Spiertz, J.H., 2009. A quantitative approach to characterize sink-source relationships during grain filling in contrasting wheat genotypes. Field Crops Res., 114(1): 119-126.

Zhao, H., Dai, T., Jing, Q., Jiang, D. and Cao, W. 2007. Leaf senescence and grain filling affected by post-anthesis high temperatures in two different wheat cultivars. Plant Growth Regulat., 51(2): 149-158.

\section{How to cite this article:}

Kang, J.S., Harmeet Singh, Maninder Kaur and Harrajdeep Kaur. 2017. Agronomic Techniques and Planting Systems Moderate Terminal Temperature Stress in Wheat. Int.J.Curr.Microbiol.App.Sci. 6(6): 1011-1017. doi: https://doi.org/10.20546/ijcmas.2017.606.117 